\title{
SOCIAL AND POLITICAL HISTORY
}

DOI: 10.46340/ephd.2020.6.1.1

Олександр Кір'яков

Київський національний університет імені Тараса Шевченка, Україна

\section{ФІВИ ТА БЕОТІЯ ПІСЛЯ БИТВИ ПРИ ПЛАТЕЯХ}

\author{
Oleksandr Kiriakov \\ ORCID ID: https://orcid.org/0000-0002-9464-7803 \\ Taras Shevchenko National University of Kyiv, Ukraine \\ THE THEBES AND BOIOTIA \\ AFTER THE BATTLE OF PLATEA
}

\begin{abstract}
Boiotia was one of the most important regions in ancient Greece. This region ruling by the Thebes became the most powerful political player in Greece in the 4 century B.C. But we don't know very well previous periods of Boiotion history. So, in this article, the author analyzes one of the most unknown periods of Boiotian history. It is the time between the battle of Platea 479 B.C. and the battle of Oenophyta 457 B.C. For better reconstruction, the author used a wide range of historical sources, which include big narratives like Herodotus or Thucydides history, or even Pindar's poetry. This article considers such problems as the existence of the Boiotian League after the battle of Platea, a form of government at the Thebes, and surviving of aristocratical elites in this period of time.

Keywords: Boiotia, Thebes, Tanagra, aristocrats, oligarchy, democrats, Athens, Sparta.
\end{abstract}

Декілька періодів історії Беотії класичної доби можна назвати погано вивченими. Це пов'язано в першу чергу з тим, що регіон в цей час не завжди був головним політичним актором Еллади, а тому випадає з поля зору джерел. До таких малознаних періодів відноситься час між двома великими битвами при Платеях та Енофітах. Перша поклала край персофільській політиці місцевих еліт. Друга ж стала початком контролю Беотії сусідніми Афінами. Власне кажучи ця стаття є спробою висвітлити головні проблеми беотійської історії цього часу. Отже, спробуємо навіть за наявної скудної джерельної виконати це завдання та окреслити хоча би і гіпотетично основні вектори розвитку регіону.

В ході греко-перських воєн всі поліси Беотії, за виключенням Феспій та Платей, дали перському царю «землю та воду». Тому відповідно після битви при Платеях в 479 р. до Р.Х. цілий регіон виявився в таборі переможених. Для персів поразка означала втрату престижу та відмову від експансіонізму на території Балканського півострова. Натомість для Беотії поразка мала більш серйозні наслідки. Регіон був безпосереднім сусідом Афінської держави, заклятого ворога персів. Беотійці понесли в першу чергу серйозні репутаційні втрати. До них в грецькому світі прикріпився епітет «свиней» ${ }^{1}$. Що ж стосується реальних наслідків, то військо грецької коаліції відразу після битви при Платеях направилось до Фів. Місто потрапило в облогу. Основною вимогою була видача олігархів, які погодились на союз із персами: Аттагіна та Тімегеніда ${ }^{2}$. Останній за словами Геродота попросив фіванців через двадцять днів осади видати тих, хто дійсно був винуватий в медизмі. Мотивом такої самопожертви аристократа було бажання врятувати місто. Інший винуватець персофільської політики Аттагін буцімто зміг врятуватися втечею. Проте спартанський полководець

\footnotetext{
${ }^{1}$ Larson, St. L. (2007). Tales of Epic Ancestry: Boiotian Collective Identity in the Late Archaic and Early Classical Periods. Stuttgart: Historia Einzelschriften, 154. ; Tufano, S. (2019). Boiotia from Within. The Beginnings of Boiotian Historiography. Münster: Universitäts und Landesbibliothek Münster, 37.

${ }^{2}$ Rockwell, N. (2017). Thebes. A History. London, New York: Routledge, 53.
} 
Павсаній навіть помилував його дітей, оскільки вони не несли провини батька. Інші ж лідери Фів, причетні до медизму, були страчені ${ }^{1}$.

Після описаних вище подій Беотія випадає з поля зору джерел. Фактично двадцять років існування цілого регіону в середній Греції відбивають лише ситуативні згадки. Такий стан справ зберігається до 457 р. до Р.Х., коли відбулися дві великі битви при Танагрі та Енофіті. Тому дуже важливо залучити максимальне коло джерел та спробувати реконструювати внутрішньополітичні події в регіоні. Найбільш важливими проблемами $є$ продовження існування регіональних політичних структур в Беотії. Та як змінилось положення Фіванського полісу в середині регіону.

Деякі дослідники вказують на те, що покарання за «медизм» було не суттєвим для регіону. Адже 3 джерел ми дізнаємось тільки про покарання фіванців і то не всіх, а тільки олігархічної верхівки. Про те, що один з іiі лідерів взагалі втік та не поніс ніякого покарання, а основна маса громадян переклала всю винну за персофільську політику на еліти чим повністю убезпечила себе від можливих наслідків ${ }^{2}$.

Скоріш за все були ще наслідки для всього регіону про які не згадує Геродот. Наприклад зберігся епіграфічний документ з Олімпії- апеляція на попереднє судове рішення, яке на жаль не зберіглося. 3 цього документу слідує що на беотійців було покладено колективне покарання. Але апеляція переглянула це рішення по відношенню до феспійців, у зв'язку з тим, що цей поліс не дав персам «землю та воду», а натомість приймав участь у Фермопільській та Платейській битвах. Документ датується періодом після Платейської битви. Тому можливо саме через позицію Феспій в греко-перському протистоянні вони були виключенні з судового рішення про санкції покладені загалом на беотійський колектив ${ }^{3}$. В даному випадку поліс був протиставлений етносу. Хоча можливі і інші пояснення, чому стосовно Феспій покарання не було застосоване ${ }^{4}$. На нашу думку перший варіант пояснення ближчий до реалій. Судячи з усього судове засідання в Олімпії стосувалось змагань. I таким чином беотійці несли ще й культурне покарання за медизм у вигляді таврування усього населення регіону як колаборантів. Оскільки Олімпійські ігри були найбільшою спортивнорелігійною подією в Елладі, репутаційні втрати мали би бути значними.

Також всупереч повідомленню Геродота про м'яке покарання фіванців багато дослідників відзначають послаблення цього полісу в регіоні. Такий висновок можна зробити не прямо, а опосередковано через гіпотезу, що в цей час гегемонію в Беотії отримує Танагра. Це припущення тісно пов'язано з позицією, що Беотійський союз після битви при Платеях продовжив своє існування і певні політичні структури могли зберегтися. Розглянемо основні постулати цієї гіпотези.

Головним доказом збереження політичних структур в Беотії слугує нумізматика. У цей період в регіоні карбували два типи монет. Перша, вироблялась в Танагрі, з зображенням традиційного «беотійського щита» та написом ВОІ. Друга, карбувалась в Танагрі, Фівах, Акрафії, Галіарті, Коронеї та просто мала зображення «беотійського щита», без напису ${ }^{5}$. Більша частина обох серій походить 3 Танагри. Це мало би свідчити про економічний спад Фів після греко-перських воєн та спроби Танагри зайняти місце гегемона ${ }^{6}$. Після перемоги при Енофіті в 457 р. до Р.Х. афіняни, згідно повідомлень джерел, зрили укріплення Танагри ${ }^{7}$. Ці факти безумовно наштовхують на думку, що Танагра стала лідером Беотійського союзу в 479-457 pp. до Р.Х. При цьому одним з основних інструментів мали би бути гроші. Тобто фінанси вже відігравали важливу роль в суспільнополітичному житті, що свідчить про високий розвиток політичного життя в Елладі в V ст. до Р.X.

Довгий час історіографія тісно пов'язувала наявність спільних для Беотії символів в чеканці монети та існування регіональних політичних структур у вигляді федерації, тощо. Однак більша частина сучасних досліджень ставить під сумнів такий зв'язок. Були вказані чисельні випадки коли спільне карбування монети не мало ніякого відношення до спільних політичних інституцій. До прикладу, спільний випуск грошей Аркадією, з написом регіонального етнікону, також довгий час

\footnotetext{
${ }^{1}$ Hdt. 9.86-88.

${ }^{2}$ Buck, R. J. (1979). A History of Boeotia. Alberta: University of Alberta Press, 135.

${ }^{3}$ Papazarkadas, N. (2014). The Epigraphy and History of Boeotia. New Finds, New Prospects. Boston, Leiden: Brill, 39-40.

${ }^{4}$ Schachter, A. (2016). Boiotia in Antiquity: Selected Papers. Cambridge: Cambridge University Press, 59-60.

${ }^{5}$ Buck, R.J. (1979). A History of Boeotia. Alberta: University of Alberta Press, 141.

${ }^{6}$ Demand, N. (1982). Thebes in the Fifth Century. Heracles Resurgent. New York: Routledge,27.

7 Thuc. 1.108 .
} 
сприймався як доказ утворення там федерації. Проте, було доведено, що спільні політичні інституції утворились там на півстоліття пізніше, а карбування монети було пов'язано виключно з святкуванням пан-аркадського фестивалю Зевса Лікейського ${ }^{1}$. Інший гарний приклад випуску грошей при відсутності політичних інституцій походить з узбережжя малої Азії. Там, Мітілени та Фокея домовились карбувати монету з електруму. Договір виявився напрочуд надійним та протримався в силі з VI по IV ст. до Р. $\mathrm{X}^{2}$. Тобто насправді існує багато неполітичних причин для карбування монети. Причини могли критися у сфері культу, як в першому випадку, так і бути суто економічними, як у другому.

Тепер, слід трохи уваги приділити ще одній нумізматичній проблемі, питанню датування цих серій монет. Справа в тім, що абсолютного датування їх не існує. Точно можна сказати лише, що це перша половина V ст. до Р.Х. Далі дослідники прив'язують певні серії монет до вагомих політичних подій ${ }^{3}$. Дійсно виглядає так, що збільшення монет з Танагри припало на послаблення Фів, яке мало би відбутися після Платейської битви. Ну і звичайно, що такий сплеск карбування мав би протривати до битви при Енофітах, адже після неї стіни Тангри були зриті в результаті чого відбулось послаблення полісу. Загалом така імовірність дійсно виглядає високою. Імовірно ми не враховуємо якісь економічні причини для такого сплеску вироблення грошей в Танагрі, які насправді мали би бути основними. Якщо Геродот правий і для Фів покаранням за «медизм» була лише страта невеликої кількості аристократів то це навряд чи могло кардинально відобразитись на їх економіці. Тому збільшення кількості монет з Танагри могло не бути пов'язано з великими битвами. Просто в результаті якихось не відомих причин цей поліс збільшив виробництво грошей, а реальні хронологічні межі цих серій могли бути відмінні від запропонованих. Також є можливість, що це статистична помилка. Монет класичної доби насправді не так багато. Знахідки кількох скарбів можуть суттєво вплинути на уявлення про співвідношення кількості обігу монет в регіоні. В такому випадку Танагра взагалі могла не мати якихось економічних успіхів в регіоні, а дослідникам просто поталанило, що скарби з їх серіями першими потрапили до їх рук.

Що ж відомо про Фіви в цей час? Насправді надійних повідомлень не так уже й багато. Так, саме в цей проміжок часу фіванцям вдалося повернути викрадену персами статую Аполлона назад в Делійське святилище. Це мало би статися в 470 р. до Р.Х. , оскільки статуя була викрадена персами в ту ж кампанію коли відбулась Марафонська битва ${ }^{4}$. Перський полководець Датіс лишив викрадену реліквію на острові Делос і наказав повернути ії власникам. Проте тільки через 20 років фіванці самі забрали іiі, буцімто по велінню бога ${ }^{5}$. Ця подія має дуже важливе значення як у сфері культу так і у сфері політики. Культ Аполлона був міським для Фів. Його вшановували в особливий спосіб за допомогою ритуалу триподофорії, тобто приношення триножників. Цей ритуал поширювався на південь та мав би символізувати єднання всіх, хто жив в цьому регіону під головуванням Фів ${ }^{6}$. Таким чином ритуал з чисто культової сфери перетікав у політичну. Адже для всього регіону на південь від Фів за допомогою культу вибудовувалась ієрархія взаємовідносин.

Також важливо наголосити на тому, що територіально святилище в Деліях мало би належати Танагрі. Насправді пізніше так і було 7 . Факт контролю Фівами святилища в Делії ставить під сумнів гіпотезу про гегемонію Танагри в Беотії. Оскільки виходить, що найсильніший поліс регіону дозволяв контроль над важливим культовим місцем на власній території.

Безумовно повернення статуї Аполона з Делосу слід розцінювати як політику по посиленню своєї позиції в регіоні ${ }^{8}$. Окрім цього, така акція не могла відбутися без згоди Афін, які повністю

\footnotetext{
${ }^{1}$ Larson, St. L. (2007). Tales of Epic Ancestry: Boiotian Collective Identity in the Late Archaic and Early Classical Periods. Stuttgart: Historia Einzelschriften, 69.

${ }^{2}$ Alfen, P. G. (2006). Agoranomia: Studies in Money and Exchange Presented to John H Kroll. New York: American Numismatic Society, 210-219.

${ }^{3}$ Larson, St. L. (2007). Tales of Epic Ancestry: Boiotian Collective Identity in the Late Archaic and Early Classical Periods. Stuttgart: Historia Einzelschriften, 71-72.

${ }^{4}$ Boardman, J., Hammond, N. G. L., Lewis, M., Ostwald, M. (1988). The Cambridge Ancient History. Cambridge: Cambridge University Press, 4, 506-517.

${ }^{5}$ Hdt.6.118.

${ }^{6}$ Papazarkadas, N. (2014). The Epigraphy and History of Boeotia. New Finds, New Prospects. Boston, Leiden: Brill, 49-50.

${ }^{7}$ Thuc. 4.76.4-5; Strabo. 9.2.7; Paus. 9.20.1.

${ }^{8}$ Buck, R. J. (1979). A History of Boeotia. Alberta: University of Alberta Press, 142.
} 
контролювали Делос. Таким чином виходить, що відбулось потепління стосунків між Фівами та Афінами ${ }^{1}$. Ворожими стосунки між двома полісами були з 519 р. до Р. $\mathrm{X}^{2}$. Тоді афіняни прийняли під свій захист Платеї. Цей союз увесь час не давав можливості розвитку відносин між Фівами та Афінами. В «школі» Еллади звичайна річ розуміли, що віддаючи статую Аполлона, посилюють позиції своїх традиційних ворогів фіванців в Беотії. Тому в них мали би бути серйозні мотиви для цього кроку.

Гарною основою для потепління стосунків могло стати введення демократичної форми правління в Фівах. Дійсно повідомлення джерел дозволяють зробити подібне припущення для періоду між 479 та 457 рр. до Р.Х. Так, Арістотель прямо вказує на те, що після битви при Енофітах тобто в 457 р. до Р.Х. в Фівах розпочалися чвари в результаті чого демократія була скасована ${ }^{3}$. Повідомлення Стагіріта може бути доповнене свідченням «Старого олігарха». Він говорить про те, що афіняни, як правило, підтримують демократії, але коли підтримали олігархів, то отримали панування над всією Беотією ${ }^{4}$. А єдиний період, коли Афіни панували в беотійському регіоні, припадає на період 457-446 pp. до Р.Х. Виходить два джерела, незалежно один від одного, повідомляють нам про, те що в Фівах до 457 р. до Р.Х. була демократична форма правління. На жаль верхню дату ії уведення точно назвати важко. Можна було би припустити, що це сталося в 479 р. до Р.Х., коли місто здалося після штурму. Але Геродот нічого не говорить про зміну форми правління. Крім того, згідно його повідомлень, наказ про старту персофілів олігархів віддав спартанський полководець Павсаній 5 . Не дивлячись на те, що Афіни і Спарта разом боролися проти персів і на той період були в гарних стосунках, важко уявити, щоб Павсаній дозволив афінянам посилити свої позиції в середній Греції. Тому демократія мала би бути запроваджена у Фівах пізніше. Імовірно це сталось до 470 р. до Р.Х. коли було повернуто статую Аполлона з Делосу. Очевидно зміна державного устрою мала якісь місцеві внутрішні причини. Досить вірогідно, що страта Павсанієм аристократів могла цьому сприяти.

Щоправда не всі дослідники погоджуються з такою інтерпретацію. Існує думка, що демократія була введена відразу після битви при Енофітах, тобто в 457 р. до Р.Х., але 3 якихось причин не прижилась та була замінена на режим якоїсь близької до Афін олігархічної партії ${ }^{6}$ Таке твердження засновано на довірі до повідомлення Діодора про те, що після битви при Енофітах Фіви не були взяті, оскільки спартанці допомогли відновити там стіну ${ }^{7}$ Афіняни врешті добились зміни державного устрою в Фівах скориставшись чи викликавши стасіс. Однак, як зазначалося вище, демократія тут не була звичною формою правління, тому до влади прийшли залежні від Афін олігархи. Це пояснення, однак, не витримує критики.

Саме повідомлення Діодора про неможливість взяття афінянами Фів після Енофіти не викликає довіри. Адже Фукідід, якого у даному випадку слід вважати більш надійним, не робить виключення для жодного з беотійських полісів. Згідно його повідомлень після Енофіти Афіни отримали панування над всією Беотією ${ }^{8}$. Джерелом Діодора для цих подій мав би бути Ефор, який жив на століття пізніше і можливо переніс політичні та військові реалії свого часу на попереднє століття. Так, спартанці діють в нього майже так само як Епамінонд століття по тому, який для протидії Лакедемону допомагав розбудовувати фортечні мури в Мессенії. Тому скоріш за все слід вважати повідомлення Діодора про відбудову стіни неправдивим і не спиратися на нього для побудови якихось інтерпретацій 9.

Отже все таки демократія мала би бути уведена в Фівах в 470-х рр. до Р.Х. та скасована після 457 р. до Р.Х., коли до влади в місті прийшли орієнтовані на Афіни олігархи. Така схема є більш прийнятною, адже не йде всупереч повідомлень таких джерел як Фукідід, «Старий Олігарх», Арістотель та дозволяє пояснити згоду Афін на повернення статуї Аполлона.

\footnotetext{
${ }^{1}$ Rockwell, N. (2017). Thebes. A History. London, New York: Routledge, 58-59.

${ }^{2}$ Thuc. 3.68.5.

${ }^{3}$ Aristot. Pol. 5. 1302b 29-32.

${ }^{4}$ Ps.Xen.Const. Ath. 3.10-11.

${ }^{5}$ Hdt.9.86-88.

${ }^{6}$ Demand, N. (1982). Thebes in the Fifth Century. Heracles Resurgent. New York: Routledge, 34.

${ }^{7}$ Diod. Sic. 11.81-83.

${ }^{8}$ Thuc. 1.108.3.

${ }^{9}$ Buck, R.J. (1979). A History of Boeotia. Alberta: University of Alberta Press, 145-147.
} 
Таким чином в результаті греко-перських воєн місцева фіванська аристократія була ослаблена настільки, що могла поступитися демократам владою в місті. Проте це не означало іiї повного знищення. $€$ цікаві поетичні свідчення Піндара про те як місцева еліта починає оговтуватись після п. Так, в першій Істмійській оді батько переможця отримав допомогу в Орхомені після корабельної аварії ${ }^{1}$. Насправді цей уривок можна читати як буквально, так і метафорично. В першому випадку цей чоловік дійсно міг зазнати якоїсь невдачі в морській справі. В другому випадку, при метафоричному прочитанні під корабельною аварією можна розуміти Платейську битву адже згідно повідомлення Геродота Асоподор командував там фіванською кіннотою ${ }^{2}$. Таким чином можливо аристократ знайшов прихисток в Орхомені. Геродот називає тільки двох головних винуватців в персофільській позиції Фів. І один з них, Аттагін, втік ${ }^{3}$. Проте, за словами того ж таки Геродота, за наказом Павсанія були страчені винні, а не лише одна людина. Тобто він очевидно називає тільки лідерів, а ще велика частина аристократів залишається не названою. Судячи з того, що втік лідер, змогли врятуватися й інші. Виходячи з повідомлення Піндара, можемо сказати, що одним з імовірних місць переховування був саме Орхомен. 3 яким мабуть Фіви, або принаймні місцеві аристократи мали би мати хороші стосунки.

Ще одним прикладом виживання та відновлення аристократичних родів можна вважати четверту Істмійську оду присвячену Меліссу з Фів. Він перемогою в змаганнях 3 панкратіону повернув славу роду, який втратив чотирьох чоловіків на війні ${ }^{4}$. Очевидно, що мається на увазі грекоперські війни. Таким чином бачимо, що один з аристократичних родів поніс прямі людські втрати, але зміг відновитись. При тому вони мали би бути достатньо заможними, щоб мати можливість заплатити такому поету як Піндар 5 .

Отже підсумовуючи слід сказати, що в нас недостатньо даних для того, щоб стверджувати, що після греко-перських воєн в Беотії зберіглися якісь регіональні інституції. Страта частини аристократів у Фівах після Платейської битви імовірно внесла плутанину в регіональні зв'язки еліт. Проте, як бачимо, частині з них вдалося не тільки вижити, а й відновитися. Це можна прослідкувати завдяки поезії Піндара. В цьому контексті цікаво виглядає той факт, що можливо частина фіванських аристократичних родин переховувались в Орхомені. Це однозначно руйнує звичний історіографічний стереотип про традиційну ворожнечу між Фівами та Орхоменом. Що стосується головування в регіоні Танагри, то ця гіпотеза має досить мало доказів на свою підтримку. Карбування монети не обов'язково прив'язане до політичних змін, а його датування часто покладається не на гіпотези, а скоріше на здогадки. Втім використання при виробництві грошей спільного регіонального символу «беотійського щита» означає збереження культових зв'язків у регіоні. Судячи по тому, що фіванські демократи повернули статую Аполлона вони так само як i ïx раніше їх родовиті візаві, використовували почуття етнічної ідентичності регіону для посилення політичної позиції свого рідного міста.

\section{References:}

1. Buck, R.J. (1979). A History of Boeotia. Alberta: University of Alberta Press. [in English].

2. Demand, N. (1982). Thebes in the Fifth Century. Heracles Resurgent. New York: Routledg. [in English].

3. Larson, St. L. (2007). Tales of Epic Ancestry: Boiotian Collective Identity in the Late Archaic and Early Classical Periods. Stuttgart: Historia Einzelschriften. [in English].

4. Papazarkadas, N. (2014).The Epigraphy and History of Boeotia. New Finds, New Prospects. Boston, Leiden: Brill. [in English].

5. Rockwell, N. (2017).Thebes. A History. London, New York: Routledge. [in English].

6. Schachter, A. (2016). Boiotia in Antiquity: Selected Papers. Cambridge: Cambridge University Press. [in English].

7. Tufano, S. (2019). Boiotia from Within. The Beginnings of Boiotian Historiography. Münster: Universitäts und Landesbibliothek Münster. [in English].

\footnotetext{
${ }^{1}$ Pind. Istm. 1. 30-40.

${ }^{2}$ Demand, N. (1982). Thebes in the Fifth Century. Heracles Resurgent. New York: Routledge, 28-29.

${ }^{3}$ Hdt.9.86-88.

${ }^{4}$ Pind. Istm. 4.

${ }^{5}$ Demand, N. (1982). Thebes in the Fifth Century. Heracles Resurgent. New York: Routledge, 29.
} 